\title{
Baccalaureate Nursing Students' Experiences of How the COVID-19 Pandemic Influenced on Learning- A Mixed Method Study
}

Gudrun Rohde ( $\square$ gudrun.e.rohde@uia.no )

University of Agder

Berit Johannessen

University of Agder

Markus Maaseide

University of Agder

Sylvi Flatland

University of Agder

Anne VS Skisland

University of Agder

Ellen B Moi

University of Agder

Kristin Haraldstad

University of Agder

\section{Research Article}

Keywords:

Posted Date: February 1st, 2022

DOI: https://doi.org/10.21203/rs.3.rs-1295793/v1

License: (a) (i) This work is licensed under a Creative Commons Attribution 4.0 International License. Read Full License 


\section{Abstract}

\section{Background}

The COVID-19 pandemic mandated the reconstruction of educational programs globally. Online distance learning, digital seminars, and supervision became the new normal. For nursing students in need of practical learning and training as a part of their curriculum, the pandemic also caused restrictions and alterations in practical placements and limited access to simulation training at campuses. The aim of this study was, therefore, to explore how the COVID- 19 pandemic influenced baccalaureate nursing students' experiences of learning

\section{Method}

We used a mixed method study design including quantitative data from one of the universities (University of Agder) from a national Norwegian survey of baccalaureate nursing students and qualitative data from focusgroup interviews from the same university. The quantitative data were analyzed using $t$-test for continuous data and chi-square test for categorical data, while the qualitative data were analyzed using Systematic Text Condensation and an editing analysis style.

\section{Results}

The quantitative survey included 396 baccalaureate nursing students (response rate, $46 \%$ ). We arranged five focus groups with a total of 23 students ( 15 female and 8 male). The students took part in one of the focusgroup interviews. Most students $(70 \%)$ were concerned about the quality of the education program. In clinical placement, $83 \%$ of students had cared for patients with confirmed COVID-19 or unclear COVID-19 status. The qualitative data revealed three main themes: missing the social dimension of learning; worries and challenges in clinical placement; and experiencing normal instructive days in clinical placement. The general picture emerging from our analysis is the importance of social interactions for learning.

\section{Conclusion}

As the COVID-19 pandemic continues, our findings of students' worries about the quality of the education program and not reaching learning outcomes must be taken into consideration. Social interaction is considered crucial and fundamental for student learning. A follow-up study following baccalaureate completion is necessary to explore the consequences over time of disrupted education.

\section{Introduction}

In March 2020, the impact of the COVID-19 pandemic enforced the reconfiguration of educational programs globally. Online distance learning, digital seminars, and supervision became the new normal [1-4]. For students in need of practical learning and training as a part of their curriculum, restrictions and alterations in practical placements and limited access to simulation training at campuses became the new normal and threatened the viability of students' education [2,5-7]. Both students and professors had to adapt to the new situation [8]. 
Nursing students may be particularly vulnerable during a pandemic, since practical and clinical training is an important part of their study where they might meet patients with COVID-19 or unclear infection status. In clinical placements, they become part of the health care system and are exposed to stressful factors, such as fear of being infected and spreading the virus to patients [9-12]. Caring for critically ill COVID patients may be challenging and may cause anxiety and stress among nursing students [13-15]. Recent studies have shown that the COVID-19 pandemic has caused a variety of challenges to nursing students globally such as uncertainty, stress, problems with concentration and learning efficiency, and fear of infection. Students were also concerned about their grades, passing their exams, the final graduation $[2,11,13,14,16-18]$, and their career ahead [11]. In addition, previous studies have identified loneliness, mental health problems, and sleeplessness among nursing students $[11,13,15]$. However, Swift et al [17] also found that nursing students in the UK expressed a sense of being a part of history, learning new things, and stepping up to a challenge that will be personally fulfilling as well as professionally worthwhile.

Most nursing programs are traditionally conducted in a face-to-face learning environment and emphasize the importance of a sociocultural perspective on learning [19]. Students are regarded as active participants and coconstructors of learning, where learning is essentially a social term rather than individual in nature and where interaction constitutes the learning process [20]. A reduced or even absent possibility for interaction due to pandemic restrictions, and use of alternative platforms such as learning management systems and web conferencing, has changed the nursing students' learning situation [1, 2].

At the current stage of the COVID-19 pandemic, most Norwegian nursing students as well as the general population are vaccinated. While statistics indicate that Norwegian society has handled the pandemic rather well, a new wave of coronavirus has arrived, and nurses and other health care providers have experienced a work overload and are exhausted [21,22]. Most inhabitants trust the governmental rules and recommendations, the transmission rate has been relatively low, there have been few hospital admissions and few deaths, and the rate of vaccinated people is high compared with other countries [21]. Despite this, Norwegian baccalaureate nursing students have been affected by restrictions depending on local and temporal variations in the transmission rate. Practical training, which is normally $50 \%$ of the three-year baccalaureate nursing program (a total of 180 European Credit Transfer System points), has proceeded with modifications [23]. During the second wave of the pandemic (January-February 2021), a national survey including five Norwegian universities showed that nursing students' academic concerns and satisfaction with the educational curriculum were significantly influenced by the pandemic, with the level of satisfaction being lower than pre-pandemic values [23]. The national survey data for baccalaureate nursing students' experiences of the learning situation exist for the five Norwegian universities [23]. However, in-depth knowledge alongside survey data seems to be lacking. The aim of this study, therefore, to explore how the COVID-19 pandemic influenced baccalaureate nursing students' experiences of learning.

\section{Methods}

\section{Design and sample}

We used a mixed method study design including quantitative data from one of the five universities (University of Agder) from the national survey [23], combined with qualitative data from the same university. The mixed 
method analysis strategy represents a parallel mixed data analysis, with separate quantitative and qualitative strands implemented to answer related aspects of the research questions regarding the same phenomenon [24]. Inferences of each strand were integrated into meta-inferences at the end of the study and are presented in the Discussion section.

Between $27^{\text {th }}$ January and $28^{\text {th }}$ February 2021 , full- and part-time baccalaureate nursing students $>18$ years of age from the two campuses at University of Agder were invited to take part in a web-based cross-sectional survey together with those from four other universities in Norway.

All three-year baccalaureate nursing students from both campuses of University of Agder were invited by the student representatives and the students learning platforms to participate in focus-group interviews on campus. The focus-group interviews took place between $26^{\text {th }}$ April and $6^{\text {th }}$ May 2021.

\section{Quantitative data}

The survey for the quantitative data included questions related to students' demographics, personal health, and study situation during the pandemic, and was specifically developed for the present research by an expert group consisting of clinicians, nursing students, university staff, and researchers. By the time of the survey, second-year and third-year students had attended 1-3 periods of clinical practice during the COVID-19 pandemic, whereas first-year students had not.

Characteristics of the respondents included age $\left(<25,25-29,{ }^{3} 30\right.$ years), household status, study site, and year of study.

The Fear of COVID-19 Scale (FCV-19S) [25], which had been adapted and assessed for use with Norwegian samples, was used [26]. Seven items (e.g., "I am most afraid of the coronavirus") were rated on a 5-point scale from 1 (strongly disagree) to 5 (strongly agree), with a total score ranging from 7 to 35 . Higher scores represent a greater fear of COVID-19. In the present study, the average item score was used. It was calculated by dividing the total score by the number of items.

COVID-19-specific questions related to personal health were developed for the national study and included quarantine history (never, previous, present); feelings of loneliness due to COVID-19 (rated from 1 [strongly disagree] to 5 [strongly agree]); perceived risk for complications of COVID-19 (no, uncertain, yes); history of suspected, possible, or confirmed COVID-19 infection; and trust in authorities' and universities' handling of the pandemic (rated from 1 [strongly disagree] to 5 [strongly agree]). In the comparative analysis, agree and strongly agree were pooled as agreed.

COVID-19-specific questions related to education addressed students' perceived impact on the different aspects of their education, especially the impacts on clinical practice and placements and the students' concern about the quality of education.

\section{Qualitative data}

We arranged five focus groups with a total of 23 students ( 15 female and 8 male). The students took part in one of the focus-group interviews. At the time of the focus-group interviews, all students had attended 1-3 
periods in clinical placement during the pandemic.

In focus groups, people with similar experiences gather together to discuss a given topic, and conversation between the participants is central [27]. The dynamics between the participants allow for insights of a different nature from those obtained through individual interviews. We used a semi-structured interview guide to ensure the inclusion of the issues in focus. The students were asked questions such as: "How much do you think that the COVID-19 pandemic has influenced your learning and learning outcomes?," "How did you experience that your placement was prepared for the COVID-19 pandemic," and "How did this influence your learning?"

\section{Analysis}

Statistical analysis: Descriptive statistics are presented for all students and for year of education specifically. Continuous variables are described as means (standard deviation [SD]), and categorical variables as counts and percentages. Associations between pairs of variables were assessed using the $t$-test for continuous data or the chi-square test for categorical data [28]. All tests were two-sided. $P$-values $<0.05$ were considered statistically significant. Furthermore, the analyses were considered exploratory, so no correction for multiple testing was performed. All analyses were performed using IBM SPSS Statistics (version 26) [28].

Qualitative analyses: We audiotaped the interviews and transcribed them verbatim. The interviews were transferred to NVivo V.12 software, to organize the transcripts into codes and units of meaning. In the analyses, we used Systematic Text Condensation and an editing analysis style [27]. Two researchers independently read all the material searching for an overall impression and established preliminary subthemes. The rest of the group read one interview each, gave input, and wrote a summary of the overall impression of the interview. We then examined the text for units of meaning representing information about students' experiences. In an iterative process, we coded and grouped these units, contrasted and abstracted the content in each group, and finally discussed and summarized the content of each group into generalized descriptions. To support the analysis, we used field notes and created mind maps, and discussed the analysis at each step to reach an agreement. Quotations were used to illustrate and support findings.

\section{User involvement}

A second-year student (MM) took part in the design and guided questions for the study. This student was also a part of the research group preparing the manuscript.

\section{Ethics}

The study was conducted according to research ethics guidelines in accordance with the Helsinki Declaration. Application was approved by the Head of Department at the University, the Norwegian Center for Research Data (Project No 973745), and the research ethics committee at the Faculty (FEK). The students received oral and written information about the study and gave their written consent to participation.

\section{Results}

\section{Quantitative data}


Three hundred and ninety-six baccalaureate nursing students (response rate, 46\%) at University of Agder participated in the survey. The majority $(70 \%)$ of students were below 25 years of age, were living with someone ( $84 \%)$, had felt lonely due to the pandemic (56\%), and had been engaged in clinical placement during the pandemic (62\%) (Table 1). Among the students, $40 \%$ had previously been or were presently in quarantine. Of the students that had been in clinical practice, $83 \%$ had cared for patients with confirmed COVID-19 or unclear COVID-19 status. Most students (72\%) had trust in the government's handling of the COVID-19 situation; the same was the case for the universities' handling of the situation (57\%). Moreover, $70 \%$ of the students were concerned about the quality of education they were receiving (Table 1). 
Table 1

Characteristics of the baccalaureate nursing students at University of Agder $(N=396)$ organized by school year

\begin{tabular}{|c|c|c|c|c|c|}
\hline & $\begin{array}{l}\text { Total } \\
\mathrm{N}= \\
396\end{array}$ & $\begin{array}{l}\text { Year } 1 \\
N=142\end{array}$ & $\begin{array}{l}\text { Year } \\
2 \\
N= \\
127\end{array}$ & $\begin{array}{l}\text { Year } \\
3 \\
N= \\
127\end{array}$ & $\begin{array}{l}P \\
\text { values* }\end{array}$ \\
\hline Years in nursing school & $\begin{array}{l}142 \\
(36 \%)\end{array}$ & & & & \\
\hline 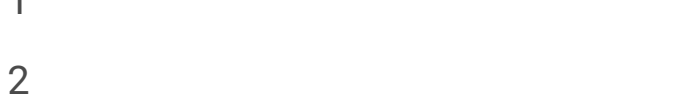 & $\begin{array}{l}127 \\
(32 \%)\end{array}$ & & & & \\
\hline 3 & $\begin{array}{l}127 \\
(32 \%)\end{array}$ & & & & \\
\hline & $\begin{array}{l}278 \\
(70 \%)\end{array}$ & $\begin{array}{l}112 \\
(79 \%)\end{array}$ & $\begin{array}{l}86 \\
(65)\end{array}$ & $\begin{array}{l}80 \\
(63 \%)\end{array}$ & 0.056 \\
\hline $25-29$ & $\begin{array}{l}46 \\
(12 \%)\end{array}$ & & $\begin{array}{l}26 \\
(20 \%)\end{array}$ & $\begin{array}{l}20 \\
(16 \%)\end{array}$ & \\
\hline$\geq 30$ & $\begin{array}{l}72 \\
(18 \%)\end{array}$ & $(13 \%)$ & $\begin{array}{l}15 \\
(12 \%)\end{array}$ & $\begin{array}{l}27 \\
(21 \%)\end{array}$ & \\
\hline & $\begin{array}{l}332 \\
(84 \%)\end{array}$ & $\begin{array}{l}120 \\
(85 \%)\end{array}$ & $\begin{array}{l}108 \\
(85 \%)\end{array}$ & $\begin{array}{l}104 \\
(82 \%)\end{array}$ & 0.764 \\
\hline Yes & $\begin{array}{l}64 \\
(16 \%)\end{array}$ & $\begin{array}{l}22 \\
(15 \%)\end{array}$ & $\begin{array}{l}19 \\
(15 \%)\end{array}$ & $\begin{array}{l}23 \\
(18 \%)\end{array}$ & \\
\hline Number of times tested for COVID-19 & $\begin{array}{l}154 \\
(39 \%)\end{array}$ & $\begin{array}{l}58 \\
(41 \%)\end{array}$ & $\begin{array}{l}46 \\
(36 \%)\end{array}$ & $\begin{array}{l}50 \\
(39 \%)\end{array}$ & 0.237 \\
\hline 1 & $\begin{array}{l}124 \\
(31 \%)\end{array}$ & $\begin{array}{l}44 \\
(31 \%)\end{array}$ & $\begin{array}{l}42 \\
(33 \%)\end{array}$ & $\begin{array}{l}38 \\
(30 \%)\end{array}$ & \\
\hline 2 & $\begin{array}{l}60 \\
(15 \%)\end{array}$ & $\begin{array}{l}15 \\
(11 \%)\end{array}$ & $\begin{array}{l}27 \\
(21 \%)\end{array}$ & $\begin{array}{l}18 \\
(14 \%)\end{array}$ & \\
\hline$\geq 4$ & $\begin{array}{l}40 \\
(10 \%)\end{array}$ & $\begin{array}{l}16 \\
(11 \%)\end{array}$ & $\begin{array}{l}10 \\
(8 \%)\end{array}$ & $\begin{array}{l}14 \\
(11 \%)\end{array}$ & \\
\hline & $\begin{array}{l}18 \\
(5 \%)\end{array}$ & $9(6 \%)$ & $\begin{array}{l}2 \\
(2 \%)\end{array}$ & $\begin{array}{l}7 \\
(6 \%)\end{array}$ & \\
\hline Quarantine status related to COVID- 19 & $\begin{array}{l}236 \\
(60 \%)\end{array}$ & $77(54 \%)$ & $\begin{array}{l}78 \\
(61 \%)\end{array}$ & $\begin{array}{l}81 \\
(64 \%)\end{array}$ & 0.383 \\
\hline $\begin{array}{l}\text { Never } \\
\text { Previous }\end{array}$ & $\begin{array}{l}157 \\
(39 \%)\end{array}$ & $\begin{array}{l}63 \\
(44 \%)\end{array}$ & $\begin{array}{l}48 \\
(38 \%)\end{array}$ & $\begin{array}{l}46 \\
(36 \%)\end{array}$ & \\
\hline Now & $\begin{array}{l}3 \\
(1 \%)\end{array}$ & $\angle(2 \%)$ & $\begin{array}{l}1 \\
(1 \%)\end{array}$ & 0 & \\
\hline
\end{tabular}

* Categorical data are presented as number (\%) and continuous variables as mean (SD). Chi-square tests were used to compare differences in categorical variables and ANOVA tests for continuous data. 


\begin{tabular}{|c|c|c|c|c|c|}
\hline & $\begin{array}{l}\text { Total } \\
\begin{array}{l}\mathbf{N}= \\
396\end{array}\end{array}$ & $\begin{array}{l}\text { Year } 1 \\
N=142\end{array}$ & $\begin{array}{l}\text { Year } \\
2 \\
N= \\
127\end{array}$ & $\begin{array}{l}\text { Year } \\
3 \\
N= \\
127\end{array}$ & $\begin{array}{l}P \\
\text { values* }\end{array}$ \\
\hline \multirow{3}{*}{$\begin{array}{l}\text { At risk for COVID-19 complications } \\
\text { No }\end{array}$} & $\begin{array}{l}49 \\
(10 \%)\end{array}$ & $\begin{array}{l}16 \\
(11 \%)\end{array}$ & $\begin{array}{l}16 \\
(13 \%)\end{array}$ & $\begin{array}{l}8 \\
(6 \%)\end{array}$ & 0.397 \\
\hline & $\begin{array}{l}323 \\
(82 \%)\end{array}$ & $\begin{array}{l}114 \\
(80 \%)\end{array}$ & $\begin{array}{l}103 \\
(81 \%)\end{array}$ & $\begin{array}{l}106 \\
(84 \%)\end{array}$ & \\
\hline & $\begin{array}{l}33 \\
(8 \%)\end{array}$ & 12 (9\%) & $\begin{array}{l}8 \\
(6 \%)\end{array}$ & $\begin{array}{l}13 \\
(10 \%)\end{array}$ & \\
\hline \multicolumn{6}{|l|}{ Uncertain } \\
\hline $\begin{array}{l}\text { Trust in governmental handling of the COVID-19 } \\
\text { situation } \\
\text { Strongly disagree/disagree } \\
\text { Neither disagree nor agree } \\
\text { Agree } \\
\text { Strongly agree }\end{array}$ & $\begin{array}{l}36 \\
(9 \%) \\
44 \\
(18 \%) \\
200 \\
(50 \%) \\
89 \\
(22 \%)\end{array}$ & $\begin{array}{l}14(6 \%) \\
30 \\
(21 \%) \\
67 \\
(47 \%) \\
31 \\
(22 \%)\end{array}$ & $\begin{array}{l}4 \\
(3 \%) \\
29 \\
(23 \%) \\
68 \\
(53 \%) \\
26 \\
(20 \%)\end{array}$ & $\begin{array}{l}18 \\
(14 \%) \\
12 \\
(9 \%) \\
65 \\
(51 \%) \\
32 \\
(25 \%)\end{array}$ & 0.016 \\
\hline $\begin{array}{l}\text { Trust in universities' handling of the COVID-19 situation } \\
\text { Strongly disagree } \\
\text { Disagree } \\
\text { Neither disagree nor agree } \\
\text { Agree } \\
\text { Strongly agree }\end{array}$ & $\begin{array}{l}18 \\
(4 \%) \\
44 \\
(11 \%) \\
112 \\
(28 \%)\end{array}$ & $\begin{array}{l}5(4 \%) \\
17 \\
(12 \%) \\
37 \\
(26 \%) \\
67 \\
(47 \%) \\
16 \\
(11 \%)\end{array}$ & $\begin{array}{l}17 \\
(13 \%)\end{array}$ & $\begin{array}{l}10 \\
(8 \%) \\
28 \\
(22 \%)\end{array}$ & 0.080 \\
\hline & $\begin{array}{l}180 \\
(46 \%)\end{array}$ & & $\begin{array}{l}50 \\
(39 \%)\end{array}$ & $\begin{array}{l}63 \\
(50 \%)\end{array}$ & \\
\hline & $\begin{array}{l}42 \\
(11 \%)\end{array}$ & & $\begin{array}{l}28 \\
(22 \%)\end{array}$ & $\begin{array}{l}17 \\
(13 \%)\end{array}$ & \\
\hline
\end{tabular}

* Categorical data are presented as number (\%) and continuous variables as mean (SD). Chi-square tests were used to compare differences in categorical variables and ANOVA tests for continuous data. 


\begin{tabular}{|c|c|c|c|c|c|}
\hline & $\begin{array}{l}\text { Total } \\
N= \\
396\end{array}$ & $\begin{array}{l}\text { Year } 1 \\
N=142\end{array}$ & $\begin{array}{l}\text { Year } \\
2 \\
N= \\
127\end{array}$ & $\begin{array}{l}\text { Year } \\
3 \\
N= \\
127\end{array}$ & $\begin{array}{l}P \\
\text { values* }\end{array}$ \\
\hline $\begin{array}{l}\text { Concern about the quality of education } \\
\text { Strongly disagree } \\
\text { Disagree } \\
\text { Neither disagree nor agree } \\
\text { Agree } \\
\text { Strongly agree }\end{array}$ & $\begin{array}{l}22 \\
(5 \%) \\
34 \\
(9 \%) \\
64 \\
(16 \%) \\
142 \\
(36 \%) \\
134 \\
(34 \%)\end{array}$ & $\begin{array}{l}3(2 \%) \\
6(4 \%) \\
17 \\
(12 \%) \\
50 \\
(35 \%) \\
66 \\
(47 \%)\end{array}$ & $\begin{array}{l}13 \\
(10 \%) \\
21 \\
(17 \%) \\
40 \\
(31 \%) \\
47 \\
(37 \%)\end{array}$ & $\begin{array}{l}13 \\
(10 \%) \\
15 \\
(12 \%) \\
26 \\
(21 \%) \\
52 \\
(41 \%) \\
21 \\
(16 \%)\end{array}$ & $<0.001$ \\
\hline Fear of COVID-19 (Mean (SD)) & $\begin{array}{l}2.3 \\
(0.7)\end{array}$ & $2.5(0.8)$ & $\begin{array}{l}2.3 \\
(0.7)\end{array}$ & $\begin{array}{l}2.2 \\
(0.7)\end{array}$ & 0.026 \\
\hline $\begin{array}{l}\text { Feeling lonely due to COVID-19 } \\
\text { Strongly disagree } \\
\text { Disagree } \\
\text { Neither disagree nor agree } \\
\text { Agree } \\
\text { Strongly agree }\end{array}$ & $\begin{array}{l}33 \\
(8 \%) \\
61 \\
(15 \%) \\
80 \\
(20 \%) \\
130 \\
(32 \%)\end{array}$ & $\begin{array}{l}8(6 \%) \\
16 \\
(11 \%) \\
23 \\
(16 \%) \\
53 \\
(37 \%) \\
42 \\
(30 \%)\end{array}$ & $\begin{array}{l}10 \\
(8 \%) \\
21 \\
(16 \%) \\
28 \\
(22 \%) \\
40 \\
(32 \%)\end{array}$ & $\begin{array}{l}15 \\
(12 \%) \\
24 \\
(19 \%) \\
29 \\
(23 \%) \\
37 \\
(29 \%)\end{array}$ & 0.096 \\
\hline $\begin{array}{l}\text { Engagement in clinical practice during the pandemic } \\
\text { Yes }\end{array}$ & $\begin{array}{l}246 \\
(62 \%) \\
150 \\
(38 \%)\end{array}$ & $\begin{array}{l}12(9 \%) \\
130 \\
(91 \%)\end{array}$ & $\begin{array}{l}117 \\
(92 \%) \\
10 \\
(8 \%)\end{array}$ & $\begin{array}{l}127 \\
(92 \%) \\
10 \\
(8 \%)\end{array}$ & $<0.001$ \\
\hline
\end{tabular}

* Categorical data are presented as number (\%) and continuous variables as mean (SD). Chi-square tests were used to compare differences in categorical variables and ANOVA tests for continuous data. 


\begin{tabular}{|c|c|c|c|c|c|}
\hline & $\begin{array}{l}\text { Total } \\
\mathrm{N}= \\
396\end{array}$ & $\begin{array}{l}\text { Year } 1 \\
N=142\end{array}$ & $\begin{array}{l}\text { Year } \\
2 \\
N= \\
127\end{array}$ & $\begin{array}{l}\text { Year } \\
3 \\
N= \\
127\end{array}$ & $\begin{array}{l}P \\
\text { values* }\end{array}$ \\
\hline \multirow[t]{7}{*}{$\begin{array}{l}\text { Have you during the pandemic been in contact with } \\
\text { patients with the following situation? }\end{array}$} & $\begin{array}{l}148 \\
(61 \%)\end{array}$ & \multirow{5}{*}{0} & $\begin{array}{l}64 \\
(55 \%)\end{array}$ & $\begin{array}{l}81 \\
(70 \%)\end{array}$ & \multirow[t]{7}{*}{$<0.001$} \\
\hline & \multirow[t]{4}{*}{$\begin{array}{l}7 \\
(3 \%)\end{array}$} & & \multirow[t]{4}{*}{$\begin{array}{l}2 \\
(2 \%)\end{array}$} & \multirow[t]{4}{*}{$\begin{array}{l}4 \\
(3 \%)\end{array}$} & \\
\hline & & & & & \\
\hline & & & & & \\
\hline & & & & & \\
\hline & $\begin{array}{l}35 \\
(15 \%)\end{array}$ & \multirow[t]{2}{*}{6} & $\begin{array}{l}11 \\
(9 \%)\end{array}$ & $\begin{array}{l}24 \\
(21 \%)\end{array}$ & \\
\hline & $\begin{array}{l}52 \\
(21 \%)\end{array}$ & & $\begin{array}{l}39 \\
(34 \%)\end{array}$ & $\begin{array}{l}7 \\
(6 \%)\end{array}$ & \\
\hline \multirow[t]{2}{*}{ Self-imposed quarantine during clinical practice } & $\begin{array}{l}105 \\
(43 \%)\end{array}$ & \multirow{2}{*}{$\begin{array}{l}2 \\
8\end{array}$} & $\begin{array}{l}43 \\
(37 \%)\end{array}$ & $\begin{array}{l}60 \\
(52 \%)\end{array}$ & \multirow[t]{2}{*}{0.025} \\
\hline & $\begin{array}{l}137 \\
(57 \%)\end{array}$ & & $\begin{array}{l}73 \\
(63 \%)\end{array}$ & $\begin{array}{l}56 \\
(48 \%)\end{array}$ & \\
\hline
\end{tabular}

The number of first-year students was 142, and that of both second-year and third-year students was 127 . When comparing students in the three different years, the most striking difference was that most first-year students had not been engaged in clinical placement during the pandemic by February 2021. This difference influenced on more second-year (66\%) and third-year students (94\%) who had been in contact with patients with confirmed or unclear COVID-19 status compared to first-year students. More first-year students (82\%) were concerned about the quality of education compared with second- $(70 \%)$ and third-year $(62 \%)$ students (Table 1). For students engaged in clinical practice (second- and third-year students), $74 \%$ reported having sufficient knowledge and skills to handle infection control due to COVID-19, 69\% were worried about contracting COVID19 , and $85 \%$ were worried about spreading the virus to patients (Table 2). Furthermore, $81 \%$ of the students were worried about too much sick (or quarantine) leave due to the required number of days to pass clinical studies, $88 \%$ were worried about not being able to finish clinical studies, $50 \%$ experienced reduced learning situations, and $25 \%$ reported insufficient guidance (see details in Table 2). There were no significant differences between second- and third-year students. 
Table 2

Learnings outcomes in clinical practice of second- and third-year $(\mathrm{N}=254)$ baccalaureate nursing students at University of Agder

\begin{tabular}{|llllllll|}
\hline & $\begin{array}{l}\text { Necessary } \\
\text { knowledge } \\
\text { of } \\
\text { infection } \\
\text { control }\end{array}$ & $\begin{array}{l}\text { Concerns } \\
\text { about } \\
\text { getting } \\
\text { infected } \\
\text { during } \\
\text { clinical } \\
\text { practice }\end{array}$ & $\begin{array}{l}\text { Concerns } \\
\text { about } \\
\text { infecting } \\
\text { patients } \\
\text { during } \\
\text { clinical } \\
\text { practice }\end{array}$ & $\begin{array}{l}\text { Concerns } \\
\text { about high } \\
\text { absenteeism } \\
\text { during } \\
\text { clinical } \\
\text { practice }\end{array}$ & $\begin{array}{l}\text { Concerns } \\
\text { about } \\
\text { completion } \\
\text { of clinical } \\
\text { practice }\end{array}$ & $\begin{array}{l}\text { Fewer } \\
\text { learning } \\
\text { situations } \\
\text { during } \\
\text { clinical } \\
\text { practice }\end{array}$ & $\begin{array}{l}\text { Insufficient } \\
\text { guidance } \\
\text { during } \\
\text { clinical } \\
\text { practice }\end{array}$ \\
\hline $\begin{array}{l}\text { Strongly } \\
\text { disagree }\end{array}$ & $4(2 \%)$ & $14(6 \%)$ & $6(2 \%)$ & $14(6 \%)$ & $8(3 \%)$ & $34(14 \%)$ & $54(22 \%)$ \\
\hline $\begin{array}{l}\text { Disagree } \\
\text { Neither }\end{array}$ & $20(8 \%)$ & $30(12 \%)$ & $23(10 \%)$ & $12(5 \%)$ & $8(3 \%)$ & $46(19 \%)$ & $84(35 \%)$ \\
$\begin{array}{l}\text { disagree } \\
\text { nor }\end{array}$ & $39(16 \%)$ & $31(13 \%)$ & $7(3 \%)$ & $19(8 \%)$ & $14(6 \%)$ & $39(16 \%)$ & $45(18 \%)$ \\
\hline $\begin{array}{l}\text { agree } \\
\text { Agree }\end{array}$ & $127(53 \%)$ & $98(40 \%)$ & $87(36 \%)$ & $61(25 \%)$ & $67(28 \%)$ & $76(31 \%)$ & $38(16 \%)$ \\
\hline $\begin{array}{l}\text { Strongly } \\
\text { agree }\end{array}$ & $52(21 \%)$ & $69(29 \%)$ & $\begin{array}{l}119 \\
(49 \%)\end{array}$ & $136(56 \%)$ & $145(60 \%)$ & $47(19 \%)$ & $21(9 \%)$ \\
\hline
\end{tabular}

No significant differences between year 2 and year 3 students were identified.

\section{Qualitative data}

Among the 23 students who took part in one of the five focus groups, the age range was 19-32 years, with a mean age of 23 years. The groups comprised 10 first-year students, seven second-year students, and six thirdyear students. All students (except 1) were living in shared accommodation or with a partner. During the analyses of the qualitative data, we identified three main themes: 1. Missing the social dimension of learning; 2. Worries and challenges in clinical placement, and 3. Experiencing normal instructive days in clinical placement. Each theme comprised two or three subthemes, illustrated in Figure 1.

\section{Missing the social dimension of learning}

Due to COVID restrictions, most tutorials and classes on campus were digital, using different platforms such as streaming, Teams, and Zoom. Most students missed the on-campus tutorials, while some were mainly satisfied with the digital ones. The digital tutorials required more discipline from students, which some of them admitted could have been better maintained. The continuity towards learning outcomes, goals, and the flow in the classes could be hard to see or follow due to digital lessons and limited dialogue. The students were worried about not reaching their learning outcomes and not being able to finish their studies. This was especially prominent among first-year students.

The quality of the digital tutorials varied, boring videos implied decreased motivation, and the students preferred digital platforms like Zoom, with the possibility for discussions. The students also noticed that most professors became more familiar with the digital teaching as time went by. The students emphasized the fact that the best professors were engaged and able to take questions at any time and not just at the end of the teaching session. In addition, the digital solutions brought freedom and flexibility. It was possible for students 
to organize their schoolwork and daily schedule as suited them best, and some even went to work in the daytime and watched educational videos in the evenings.

"I have enjoyed extremely well the opportunity to replay the videos, realize them properly, and use breaks to take notes. I did not have to stress about writing." (Focus group nr 5)

The students missed face-to-face discussions and dialogue with fellow students and the professors. They missed the opportunity to ask questions and to get to know other students and the professors. This was especially true among first-year students. Some first-year students felt alone and knew only a few fellow students, admitting it was hard to take the initiative to get to know fellow students better. Two students considered leaving the university or starting again after the pandemic. Furthermore, students with learning disability found it hard not to be able to see the professors in person and ask questions when needed.

"You get a lot of free learning from going to campus. You may ask your fellow students or your professor if you did not understand something, and then maybe you start a discussion in a group. This is something you don't get the opportunity to do now." (Focus group nr 3)

To get to know fellow students and the professors was considered important for optimal learning. The digital solutions made it hard to meet fellow students, and it was difficult to establish new friendships. The social part of being a student and the possibility to see other students was emphasized as important for student learning and well-being. The students' motivation for learning decreased, so did their feeling of university belonging.

"You don't belong. You lose your sense of purpose." (Focus group nr 5)

Second- and third-year students underlined the importance of the "free learning" they received when they had the opportunity to attend campus, ask questions, discuss, and revise a lesson. Students with an established network felt more privileged than first-year students. Some students went to the university library just to watch digital tutorials and meet a few fellow students during breaks. One of the year 2 students said,

"I am very happy that I was in year 2 and not in year 1 when the society went into lockdown." (Focus group nr 2)

\section{Worries and challenges in clinical placement}

In contrast to most other universities, the students at the present university were able to attend clinical placements nearly as much as before the pandemic, and they really appreciated it. Although the students were able to attend clinical practice, they were worried about not reaching learning outcomes. The students were worried about not being able to fulfill the number of hours and days required in clinical studies and afraid of not qualifying for nursing registration. A COVID-19 infection or period of quarantine could easily cause such a situation.

"It is not just the fear of catching the virus or spreading the virus but also the fear of the consequences of a positive test and the quarantine. Do I have to postpone my authorization as a nurse due to lack of clinical practice?" (Focus group nr 5) 
Some students did not meet some of the required learning outcomes, while others' experience was to reach them satisfactorily. It had recently been a discussion among the students about a generation of nurses receiving a second-best education due to lack of experience and learning; however, most of the students in the present study did not feel so.

"There are several nursing students at other universities in the country who are going to finish their studies this spring who feel they will end as a second-best nurse. This is not the case for us. I feel like a trained and proper nurse." (Focus group nr 2)

The students had to adapt to the national restrictions and rules, which constantly varied during the first year of the pandemic due to transmission rate and number of vaccinated patients and staff. The guidelines from the university were unclear, especially in the beginning of the pandemic. A few students experienced a placement that did not want students due to work overload and unclear situations, although most students were satisfied with their supervisors who had walked the extra mile to assist them.

Fear of catching the virus themselves or spreading the virus to patients, family, and fellow students when in clinical studies was emphasized by all students. Several nursing homes in the region had experienced COVID19 infections among patients and staff, and recently a nursing student had been responsible for bringing the infection into the ward. They were afraid of being the student who brings the infection and causes death.

"I can imagine the newspaper; nursing student brought the virus into the nursing home and 5 patients died." (Focus group nr 4)

As a result of contact with a high number of persons in clinical practice, the students reduced the number of persons they met in their spare time.

\section{Experiencing normal instructive days in clinical placement}

The students found that clinical practice brought routine into their lives. They were practicing meaningful newly-learned skills. Especially, the first-year students felt that they finally were able to have a more normal life. They experienced having a routine, a social life of sorts, and colleagues. In clinical practice, several of the students had met COVID-19-infected patients and patients with unclear COVID-19 status. In the emergency ward, some had been in the frontline and seen how severely ill the patients could be. Furthermore, they experienced all the extra precautions and the extra work this entailed. They witnessed the nurses' extra workload, working double shifts to cover up and taking care of lonely patients. As a result of these experiences, they felt an extra responsibility to take preventive action to not spread the virus.

"I was in the frontline at the emergency ward and saw how severely ill the patients could be." (Focus group nr 4)

Furthermore, as nursing students they were expected to have more than average knowledge about hygiene and infection control. They felt responsibilities to act as role models. One student highlighted this and said,

"I remember my own attitude to hygiene before the corona. I could be sloppy sometimes. But now I wash my hands all the time. So, I have developed increased awareness in hygiene." (Focus group nr 4)

Page 13/19 
Being in clinical practice also implied seeing more people, which influenced their total numbers of contacts and the numbers of recommended contacts. The students experienced friends and other students not following the rules and felt disappointed. Some even terminated friendships due to this experience. They more-or-less acted as "head of infection control." Being "inside" the pandemic brought new perspectives. The students had experienced the overwhelming workload within the health care system through the pandemic, gaining a perspective that other students may miss.

\section{Discussion}

The aim of this study was to explore how the COVID-19 pandemic influenced baccalaureate nursing students' experiences of learning. The general picture that emerges from our analysis is the importance of social interactions for learning [20]. The nursing students missed the face-to-face contact with their peers and professors that was replaced mainly with digital teaching and emphasized the importance of social interaction as an important factor for learning. They also missed the forum for discussing their experiences. The students were worried about not reaching learning outcomes and had worries and challenges in clinical placement. However, they experienced more normal days in clinical placement and a feeling of being a part of the history.

The nursing students experienced a fear of not reaching learning outcomes both in theoretical classes and clinical practice because of all the adaptations and restrictions imposed due to the COVID-19 pandemic. These findings are in line with previous studies where nursing students had problems with concentration and learning efficiency, fear of COVID-19, their grades, final graduation, and future career [11, 14, 18]. Looking closer into the numbers in the national survey [23], more students in the present university reported satisfaction with the university's handling of the situation and were less concerned about the quality of the education compared with other universities (Supplementary Tables 1 and 2). Such findings were most likely associated with the relatively low transmission rate during the pandemic and local restrictions in the university region [21], along with nearly normal maintenance of clinical practice, which was not seen in the other universities [5]. Despite this, our students experienced fear of not reaching their learning outcomes, experienced stress, missed their peers and friends, and experienced fear of COVID.

The fear of COVID and its concomitant restrictions hampered the possibilities and advantages that social interactions bring to learning [20]. A recent study from Sweden [29] showed that while some of the nursing students preferred digital learning and use of digital tools, the majority said that digital learning reduced their opportunities for social interaction and felt that this reflected negatively on their learning process. Moreover, students reported that the reduced social interaction had a negative effect on their mental health [29]. In most nursing education, learning is regarded as a social experience rather than an isolated one, and social interaction is a significant element in the learning process [20]. Reduced social interaction affects both the learning process and the students' mental health. The results from our study showed that first-year students were more vulnerable than second- and third-year students. They felt lonely and some of them had few fellow students. The pandemic forced the professors to start with digital teaching instead of traditional campusbased teaching, and most of the professors were not prepared for this. A longer preparation time might have resulted in the development of learning activities that better supported social interaction, such as digital groups and discussion [8]. Although the students in our study were able to attend clinical practice, they were worried 
about not reaching expected learning outcomes and not being able to fulfill the number of days required in clinical studies.

Both the quantitative and qualitative data show that first-year students are more vulnerable than second- and third-year students. This might be because first-year students have not yet been able to meet each other faceto-face, are not used to being tertiary students, and are strongly affected by the uncertainty of the future. Already at the beginning of the nursing program, they were worried about not being able to complete their education and become a nurse. Living with such uncertainty and stress may have a negative impact on the learning process $[14,15,18]$.

Despite the nursing students' fear and struggles, they were also grateful for the experience of being a part of a historical tradition. Some studies show that the status of nursing has risen during the pandemic [30]. Our findings are in line with those of Swift et al [17] who showed that where students successfully stepped up to a learning challenge, they found it both personally fulfilling and professionally worthwhile. Such experiences were mostly related to the students' clinical placement, where several students in our study told stories about how they had become "a positive difference" for the patients and in the ward.

\section{Strengths and limitations}

Strengths of the study are that nearly half of the students at the present university participated in the crosssectional survey, and the proportion of students in the three different years was close to the same. Quantitative data were collected using well-validated questions and questionnaires, most of them used in previous student surveys in Norway [5].

Limitations with the present study are the cross-sectional nature of the survey, which reveals only statistically significant associations between the variables and does not allow one to draw conclusions about causality. We have no information about the students not taking part in the survey. However, quantitative results were combined with qualitative findings to give a more comprehensive picture of the students' experiences. Further limitations are that the findings from the qualitative part of the study represent only input from the students in the focus groups and only at one point in time.

\section{Implications}

It is of great importance for most of the students that their life is predictable, and they have a sense of purpose through their years as a student, despite a pandemic. This becomes extremely important for first-year students. The results show that the social learning environment in the future should be safeguarded by offering both digital and physical teaching (lectures and simulation) on campus. Moreover, the results emphasized the importance of social interactions for learning, and that the universities need to develop strategies that compensate for the lack of social interaction to improve the students' well-being and psychosocial health.

Clinical placement met students' needs for social and academic meetings, as well as individual meetings with professors, and must be preserved and strengthened as a learning forum in future pandemics and other demanding situations. Furthermore, professors must maintain the ability to think of alternative learning strategies that can be implemented quickly in the event of future pandemics (or other crises). 


\section{Conclusion}

The COVID-19 pandemic influenced nursing students' learning significantly. Most of the students were concerned about the quality of their education and were worried about excessive absence from practical placements due to COVID infection or quarantine. The students missed their face-to-face contact with their peers and professors, which underlined the importance of social interaction for learning. Despite challenges in clinical practice, the students appreciated the experience of being a part of history. The challenges of the students' experiences must be incorporated into the university's curriculum and teaching.

\section{Declarations}

Ethics approval: All procedures performed in the study were in accordance with the ethical standards of the institutional and/or national research committee and the 1964 Helsinki declaration and its later amendments or comparable ethical standards. Approval was obtained from the ethics committee of the Faculty of Health and Sport Sciences at the University of Agder and from the Norwegian Centre for Research Data (NSD Reference 60981).

Consent to participate: The students received written information and gave their informed consent. Data in the study were anonymized.

Consent for publication: Not applicable.

Data and materials availability: The datasets used and/or analyzed during the current study are not publicly available due to General Data Protection Regulation laws but are available from the corresponding author on reasonable request and with permission from the Norwegian Centre for Research Data.

Competing interest: The authors declare that they have no competing interests.

Funding: Faculty of Health and Sport Sciences, University of Agder.

Authors' contributions: The study was designed by GR and KH. MM gave valuable input to the national survey.GR and KH were responsible for the recruitment and focus-group interviews. Quantitative data analysis was performed by GR. GR was mainly responsible for the qualitative analysis, but all authors gave input and contributed. The first draft of the manuscript was written by GR, and all authors commented on previous and current versions of the manuscript. All authors read and approved the final manuscript.

Acknowledgements: We would like to thank all the nursing students at University of Agder who participated in this study, thereby providing us with valuable research data.

\section{Authors information}

Title and email addresses of the authors:

Professor and PhD Gudrun Rohde: gudrun.e.rohde@uia.no

Associated professor and PhD Berit Johannessen: Berit.Johannessen@uia.no 
Nursing student Markus Maaseide: markusmaaseide@gmail.com

Professor Sylvi Flateland: sylvi.flateland@uia.no

Professor Anne Valen-Sendstad Skisland: anne.skisland@uia.no

Associated professor Ellen Benestad Moi: ellen.b.moi@uia.no

Professor and PhD Kristin Haraldstad: kristin.haraldstad@uia.no

16-digit ORCID of the authors

Gudrun Rohde: 0000-0002-8538-7237

Berit Johannessen:-0000-0003-4648-4947

Markus Måseide

Sylvi Flateland: 0000-0002-8149-4203

Anne Skisland: 0000-0001-7409-5530

Ellen Benestad Moi: 0000-0003-0425-8255

Kristin Haraldstad: 0000-0002-7364-147X

\section{References}

1. Lengetti E, Cantrell MA, DellaCroce N, Diewald L, Mensinger JL, Shenkman R: Learning environment and evidence among professionals and students satisfaction (LEAPS), experienced during the COVID-19 pandemic. Teach Learn Nurs 2021, 16(4):342-346.

2. Dewart G, Corcoran L, Thirsk L, Petrovic K: Nursing education in a pandemic: Academic challenges in response to COVID-19. Nurse Educ Today 2020, 92:104471.

3. Rossini S, Bulfone G, Vellone E, Alvaro R: Nursing students' satisfaction with the curriculum: An integrative review. J Prof Nurs 2021, 37(3):648-661.

4. Guldager JD, Jervelund S, Berg-Beckhoff G: Academic stress in Danish medical and health science students during the COVID-19 lock-down. Dan Med J 2021, 68(7).

5. The Student Survey 2021 [https://studiebarometeret.no/en/student/studieprogram/1175_syplgr/.]

6. Education Shift During COVID-19: Students' Satisfaction with Emergency Distance Learning. International journal of nursing education 2021.

7. Ard N, Beasley SF, Nunn-Ellison K, Farmer S: Responding to the pandemic: Nursing education and the ACEN. Teach Learn Nurs 2021, 16(4):292-295.

8. Utvær BKS, Paulsby TE, Torbergsen H, Haugan G: Learning nursing during the COVID-19 pandemic: The importance of perceived relatedness with teachers and sense of coherence. 2021. 
9. Leigh J, Bolton M, Cain K, Harrison N, Bolton NY, Ratcliffe S: Student experiences of nursing on the front line during the COVID-19 pandemic. British Journal of Nursing 2020, 29(13):788-789.

10. Lovrić R, Farčić N, Mikšić Š, Včev A: Studying During the COVID-19 Pandemic: A Qualitative Inductive Content Analysis of Nursing Students' Perceptions and Experiences. Education Sciences 2020, 10(7):188.

11. Gallego-Gómez JI, Campillo-Cano M, Carrión-Martínez A, Balanza S, Rodríguez-González-Moro MT, Simonelli-Muñoz AJ, Rivera-Caravaca JM: The COVID-19 Pandemic and Its Impact on Homebound Nursing Students. Int J Environ Res Public Health 2020, 17(20).

12. Ulenaers D, Grosemans J, Schrooten W, Bergs J: Clinical placement experience of nursing students during the COVID-19 pandemic: A cross-sectional study. Nurse Educ Today 2021, 99:104746.

13. Romero-Blanco C, Rodríguez-Almagro J, Onieva-Zafra MD, Parra-Fernández ML, Prado-Laguna MDC, Hernández-Martínez A: Sleep Pattern Changes in Nursing Students during the COVID-19 Lockdown. Int J Environ Res Public Health 2020, 17(14).

14. Aslan H, Pekince H: Nursing students' views on the COVID-19 pandemic and their percieved stress levels. Perspect Psychiatr Care 2021, 57(2):695-701.

15. Nurunnabi M, Almusharraf N, Aldeghaither D: Mental health and well-being during the COVID-19 pandemic in higher education: Evidence from G20 countries. J Public Health Res 2020, 9(Suppl 1):2010.

16. Eiguren A, Idoiaga N, Berasategi N, Picaza M: Exploring the Social and Emotional Representations Used by the Elderly to Deal With the COVID-19 Pandemic. Front Psychol 2020, 11:586560.

17. Swift A, Banks L, Baleswaran A, Cooke N, Little C, McGrath L, Meechan-Rogers R, Neve A, Rees H, Tomlinson A et al: COVID-19 and student nurses: A view from England. J Clin Nurs 2020, 29(17-18):31113114.

18. Savitsky B, Findling Y, Ereli A, Hendel T: Anxiety and coping strategies among nursing students during the covid-19 pandemic. Nurse Educ Pract 2020, 46:102809.

19. Carlson E, Stenberg M: Peer learning-making use of sociocultural theory. Nurse Educ Pract 2020, 46:102819.

20. Beccaria L, Kek M, Huijser H: Exploring nursing educators' use of theory and methods in search for evidence based credibility in nursing education. Nurse Educ Today 2018, 65:60-66.

21. COVID - 19 Dashboard by the Center for Systems Science and Engoneering (CSSE) at John Hopkins University (JHU) [https://www.arcgis.com/apps/dashboards/bda7594740fd40299423467b48e9ecf6]

22. While AE, Clark LL: Management of work stress and burnout among community nurses arising from the COVID-19 pandemic. Br J Community Nurs 2021, 26(8):384-389.

23. Beisland EG, Gjeilo KH, Andersen JR, Bratås O, Bø B, Haraldstad K, Hjelmeland IHH, Iversen MM, Løyland B, Norekvål TM et al: Quality of life and fear of COVID-19 in 2600 baccalaureate nursing students at five universities: a cross-sectional study. Health Qual Life Outcomes 2021, 19(1):198.

24. Polit DF: Nursing research: principles and methods. Philadelphia, Pa.: Lippincott Williams \& Wilkins; 2004.

25. Ahorsu DK, Lin CY, Imani V, Saffari M, Griffiths MD, Pakpour AH: The Fear of COVID-19 Scale: Development and Initial Validation. Int J Ment Health Addict 2020:1-9.

26. Iversen MM, Norekvål TM, Oterhals K, Fadnes LT, Mæland S, Pakpour AH, Breivik K: Psychometric Properties of the Norwegian Version of the Fear of COVID-19 Scale. Int J Ment Health Addict 2021:1-19. 
27. Crabtree BF, Miller WL: Doing qualitative research. Thousand Oaks, Calif.: Sage; 1999.

28. Pallant J: SPSS survival manual: a step by step guide to data analysis using IBM SPSS, 6th ed. edn. Maidenhead: McGraw Hill Education; 2016.

29. Langegård U, Kiani K, Nielsen SJ, Svensson PA: Nursing students' experiences of a pedagogical transition from campus learning to distance learning using digital tools. BMC Nurs 2021, 20(1):23.

30. Rossi S, Cosentino C, Bettinaglio GC, Giovanelli F, Prandi C, Pedrotti P, Preda D, D'Ercole A, Sarli L, Artioli G: Nurse's identity role during Covid-19. Acta Biomed 2021, 92(S2):e2021036.

\section{Figures}

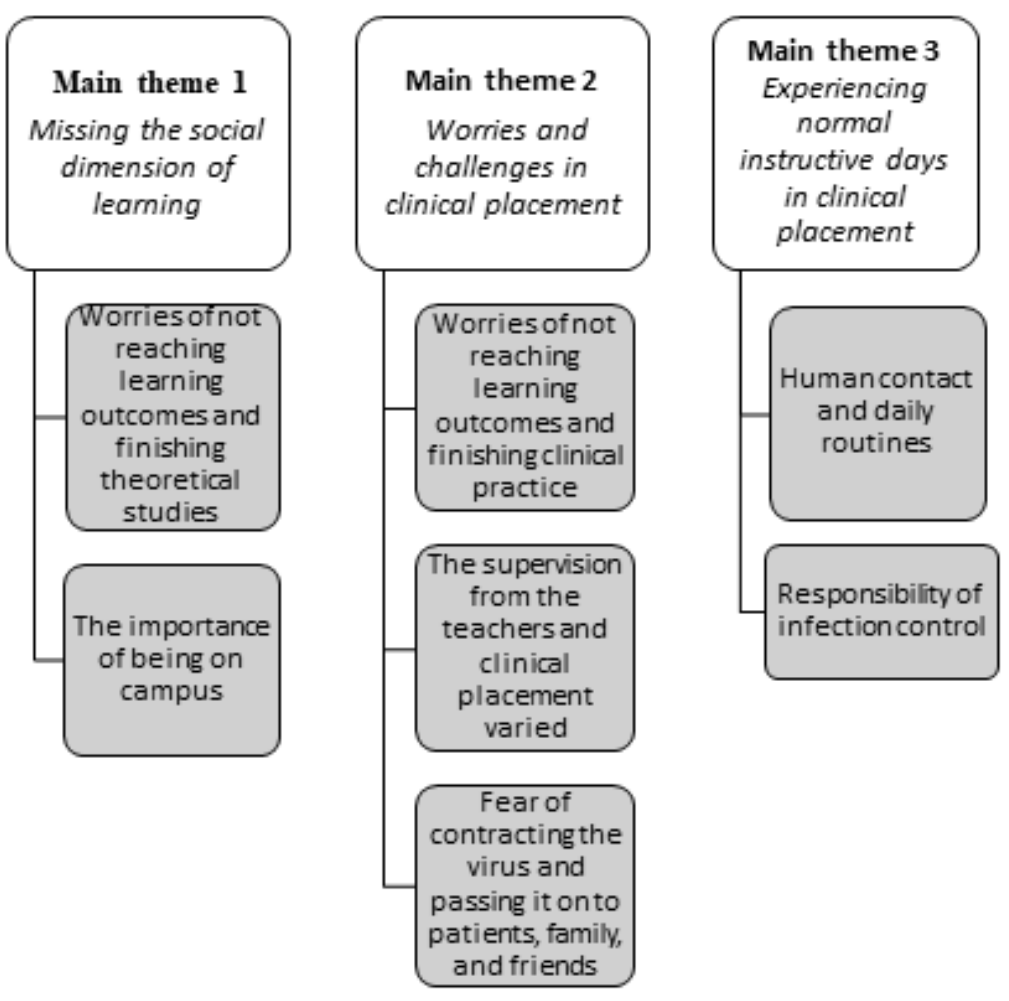

\section{Figure 1}

Main themes and subthemes of how the covid 19 pandemic influenced baccalaureate nursing students' experiences of learning.

\section{Supplementary Files}

This is a list of supplementary files associated with this preprint. Click to download.

- 25.01.22GudrunRohdeSupplementary.docx 